University of Nebraska - Lincoln

DigitalCommons@University of Nebraska - Lincoln

Biological Systems Engineering: Papers and

Publications

Biological Systems Engineering

8-19-1999

\title{
Nutrient Balance on Nebraska Livestock Confinement Systems
}

Richard K. Koelsch

University of Nebraska-Lincoln, rkoelsch1@unl.edu

Gary Lesoing

University of Missouri Outreach and Extension, Richmond, MO, glesoing2@unl.edu

Follow this and additional works at: https://digitalcommons.unl.edu/biosysengfacpub

Part of the Biological Engineering Commons

Koelsch, Richard K. and Lesoing, Gary, "Nutrient Balance on Nebraska Livestock Confinement Systems" (1999). Biological Systems Engineering: Papers and Publications. 7.

https://digitalcommons.unl.edu/biosysengfacpub/7

This Article is brought to you for free and open access by the Biological Systems Engineering at DigitalCommons@University of Nebraska - Lincoln. It has been accepted for inclusion in Biological Systems Engineering: Papers and Publications by an authorized administrator of DigitalCommons@University of Nebraska Lincoln. 


\title{
Nutrient Balance on Nebraska Livestock Confinement Systems
}

\author{
Rick Koelsch* and Gary Lesoing ${ }^{\dagger}$ \\ *Biological Systems Engineering Department, University of Nebraska-Lincoln 68585-0726 and \\ tUniversity of Missouri Outreach and Extension, Richmond, MO 64085
}

\begin{abstract}
Managing the environmental risk associated with livestock production is a significant challenge. Nitrogen and phosphorus are commonly implicated as the sources of ground and surface water quality problems associated with livestock production. The degree of imbalance between these nutrient inputs and the managed nutrient outputs for a livestock operation defines the magnitude of potential environmental risk and provides insight as to the underlying causes of these challenges. A nitrogen and phosphorus balance was constructed for 33 Nebraska confinement livestock operations. Twenty-five and 17 of these operations experienced significant nitrogen and phosphorus imbalances, respectively (50\% more nutrient inputs than outputs). Nutrient inputs on many livestock operations were observed to be two to
\end{abstract}

four times greater than nutrient outputs as managed crop and livestock products. Size of the livestock operation and the degree of integration of livestock with a cropping operation provided only limited explanation of the variation in nutrient balance observed among the individual operations. Management options that contribute to a more favorable nutrient balance were also identified. Management decisions related to feeding program and exporting of manure nutrients to off-farm users were observed to have a substantial impact on the nutrient imbalance. For modern livestock production systems to successfully respond to nutrient-related environmental problems, management strategies must be implemented that address the commonly experienced imbalances of nitrogen and phosphorus.

Key Words: Nutrient Balance, Animal Manures, Nitrogen, Phosphorus

C)1999 American Society of Animal Science and American Dairy Science Association. All rights reserved.

\section{Introduction}

Nitrogen and phosphorus losses are critical water quality issues associated with livestock manure. Nitrate-nitrogen is a regulated drinking water contaminant of concern because of blue baby syndrome. Ammonia-nitrogen and phosphorus in surface water present risks of toxicity to fish and accelerated eutrophication (CAST, 1996).

Livestock and poultry in the United States produce 3.2 and 2.8 million $\mathrm{Mg}$ (3.5 and 3.1 million tons) of plant-available nitrogen and phosphorus, respectively (CAST, 1996). Manure was the source of $37 \%$ of all nitrogen and $65 \%$ of all phosphorus going into watersheds in the central states, including Nebraska (Lugar and Leaky, 1995). Livestock producers have a growing ethical responsibility to manage for a balanced nutrient system.

Solutions to nutrient-related issues require an understanding of the flows of nutrients on livestock farms (Figure 1). Nutrients arrive on livestock farms (inputs) as purchased feed, purchased fertilizer, purchased animals, nitrogen fixed by legume crops, and nitrogen in irrigation water. Multiple options also exist for nutrients to leave the farm, preferably as managed outputs such as milk, animals, or crops.

The difference between nutrient inputs and managed nutrient outputs is an indication of environmental risk. This imbalance is either 1 ) lost to the environment directly or 2) added to nutrient reserves in the soil, increasing the risk for future environmental losses (Klausner, 1995). Achievement of a nutrient balance between the nutrient inputs and managed outputs is key to minimizing the nutrientrelated environmental risk associated with livestock production. The intent of this review is to define a nutrient balance on Nebraska livestock confinement operations and identify characteristics or management practices that minimize the imbalance of nutrients. 


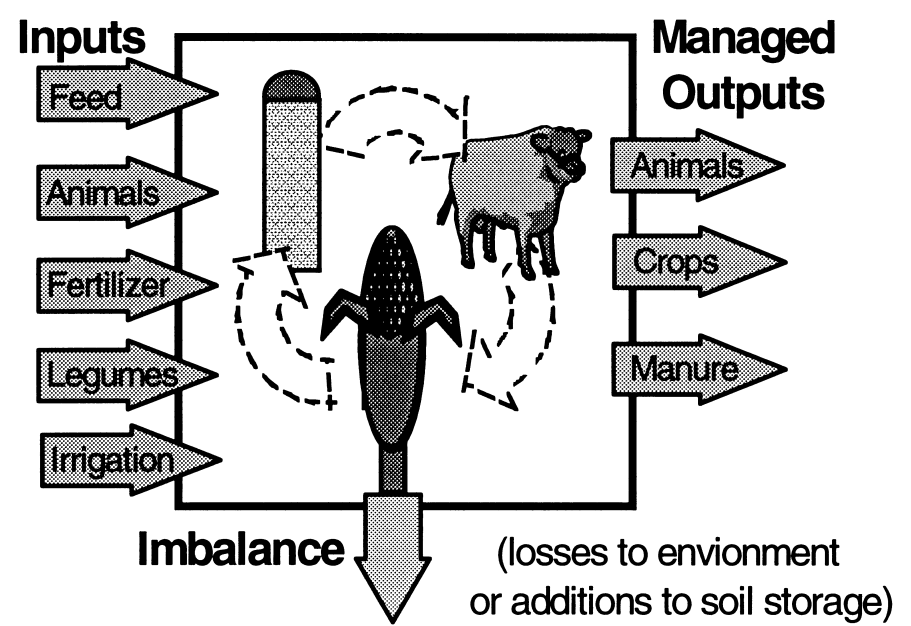

Figure 1. Balance between nutrient inputs and managed outputs is an indicator of nutrient imbalance (losses to the environment and additions to soil storage).

\section{Literature Review}

An imbalance or accumulation of nutrients on livestock operation is reported to be a driving force behind the potential environmental risk (Frink, 1969; Aarts et al., 1992; Lanyon and Beegle, 1993; Watts et al., 1994; Klausner, 1995). The imbalance between total nitrogen inputs and managed outputs was observed to be $84 \%$ for a Pennsylvania dairy (L anyon and Beegle, 1989), between 59 to $79 \%$ for $17 \mathrm{New}$ York dairies (Klausner, 1995), and $86 \%$ on a typical Dutch dairy farm (Aarts et al., 1992). (Here the percentages indicate the portion of nutrients in the inputs that is not accounted for in the managed outputs.) Watts et al. (1994) observed an imbalance ranging from 36 and $66 \%$ of all imported phosphorus within two Australian beef feedlots and supporting cropland representing $39 \mathrm{Mg}$ and $161 \mathrm{Mg} \mathrm{(43}$ and 177 tons) of phosphorus added to the farms. A mass nitrogen balance by Smolen et al. (1994) for Texas (large beef population) and Adair (large poultry population) counties in Oklahoma suggested an annual nitrogen imbalance within these counties of $51 \%$ $(12,400 \mathrm{Mg})$ and $53 \%(2,400 \mathrm{Mg})$ of all imported nitrogen, respectively.

Several factors contribute to the large nutrient imbalance characteristic of many modern livestock operations. Lanyon and Beegle (1993) suggested that nutrients are imported onto modern "crop/livestock" farms in proportion to animal needs rather than crop production needs. The strong physical and economic ties between nutrient inputs and managed outputs for crop production systems are less apparent in livestock production. This is a result, in part, from the inefficiencies of nutrient utilization within livestock production. Yearling cattle retain only 10.4 and $18.5 \%$ of the nitrogen and phosphorus fed, respectively (Klopfenstein et al., 1995), whereas a 90-kg finishing pig retains only $39 \%$ of the nitrogen in the feed (Cromwell and Coffey, 1995). Most nutrients fed to animals are not marketed as meat or other products but remain on the farm in manure.

Manure nutrients are typically "recycled" in a cropping system. As livestock operations become more concentrated, more feeds are purchased from off-farm sources. Purchased feed has become the primary nutrient input to many modern livestock farms (Lanyon and Beegle, 1989; Smolen et al., 1994; Klausner, 1995). This change also provides less opportunity for recycling manure nutrients within the available land base accessible to the livestock operation. Klausner (1995) observed that as the land base decreases relative to animal numbers, the nutrient imbalance appears to be a larger fraction of the total nitrogen and phosphorus inputs to those farms.

\section{Procedure}

To better understand this issue, a study was initiated with the following objectives: 1) Define the source and magnitude of nutrient inputs, outputs, and resulting imbalance for representative confinement livestock operations in Nebraska. 2) Identify characteristics and management practices of these livestock systems that explain observed variations in nutrient balance with the intent of defining situations that contribute to better nutrient balance.

Approximately 110 livestock operators were approached, of which 40 agreed to participate in a survey of nutrient balance. A personal visit was made to each cooperator, during which the desired information was collected and a preliminary nutrient balance was completed. Complete data from 33 farms are included in the analysis.

An accounting of nutrient inputs (purchased feed, purchased fertilizer, purchased animals, biologically fixed nitrogen, and nitrogen in irrigation water) and managed nutrient outputs (animals, crops and manure moved off farm) was completed for 16 cattle feedlots and 17 swine confinement operations (see Figure 1). Procedures used by Klausner (1995) and Lanyon and Beegle (1989) were used in constructing a nutrient balance with two exceptions. First, changes in farm nutrient inventory (e.g., stored crops, feed, 
and fertilizer) were also included in the analysis. Second, the nutrient imbalance is expressed as a ratio of nutrient inputs to outputs (as opposed to a percentage of inputs) to provide a more direct measure of the relationship between inputs to outputs. An input-to-output ratio of 2:1 suggests that twice as much nutrient is being brought onto the farm as leaves the farm in managed products. It also implies that $50 \%$ of the inputs are added to the environment (air, water, or soil). The value is calculated as follows:

$$
\begin{gathered}
\text { Nutrient imbalance ratio }= \\
\text { inputs }+ \text { change in input inventory } \\
\hline \text { outputs }+ \text { change in output inventory }
\end{gathered}
$$

The nutrient concentration of various inputs and outputs are defined in Table 1. Typically, a livestock operation provided an individual farm analysis for nutrient concentration of purchased feeds and manure marketed to off-farm customers. Standard values and producer knowledge of purchased product were typically used for fertilizer nutrient concentration. Feed table values (NRC, 1996) were commonly used for marketed crops and occasionally for purchased feeds.
A literature review provided the basis for the selected values for nutrient concentrations of animals (see Table 1). Assumed nutrient concentrations as were commonly used for animal products, marketed crops, and nitrogen fixed by legumes may vary from actual values resulting in differences between actual and calculated nutrient balances.

Both a nitrogen and phosphorus balance are presented. A phosphorus balance provides a preferred indication of the degree of risk to water quality. An imbalance in nitrogen does not distinguish between the relatively benign volatilization losses of ammonia to the atmosphere and the relatively harmful losses of nitrate to water. Volatilization losses from open lots, anaerobic lagoons, or surface application of manure can be large. In contrast, phosphorus losses impact only water quality through increased soil phosphorus levels and greater concentration of phosphorus moving with surface runoff water. A relative balance between phosphorus inputs and managed outputs would suggest that the risk to water quality remains relatively constant and thus a potentially "sustainable" system exists. A phosphorus imbalance would suggest an increasing risk to water quality alone, whereas a nitrogen imbalance would suggest an increasing risk to both air and water resources.

Table 1. Nutrient concentrations and assumption used for estimating nutrient balance

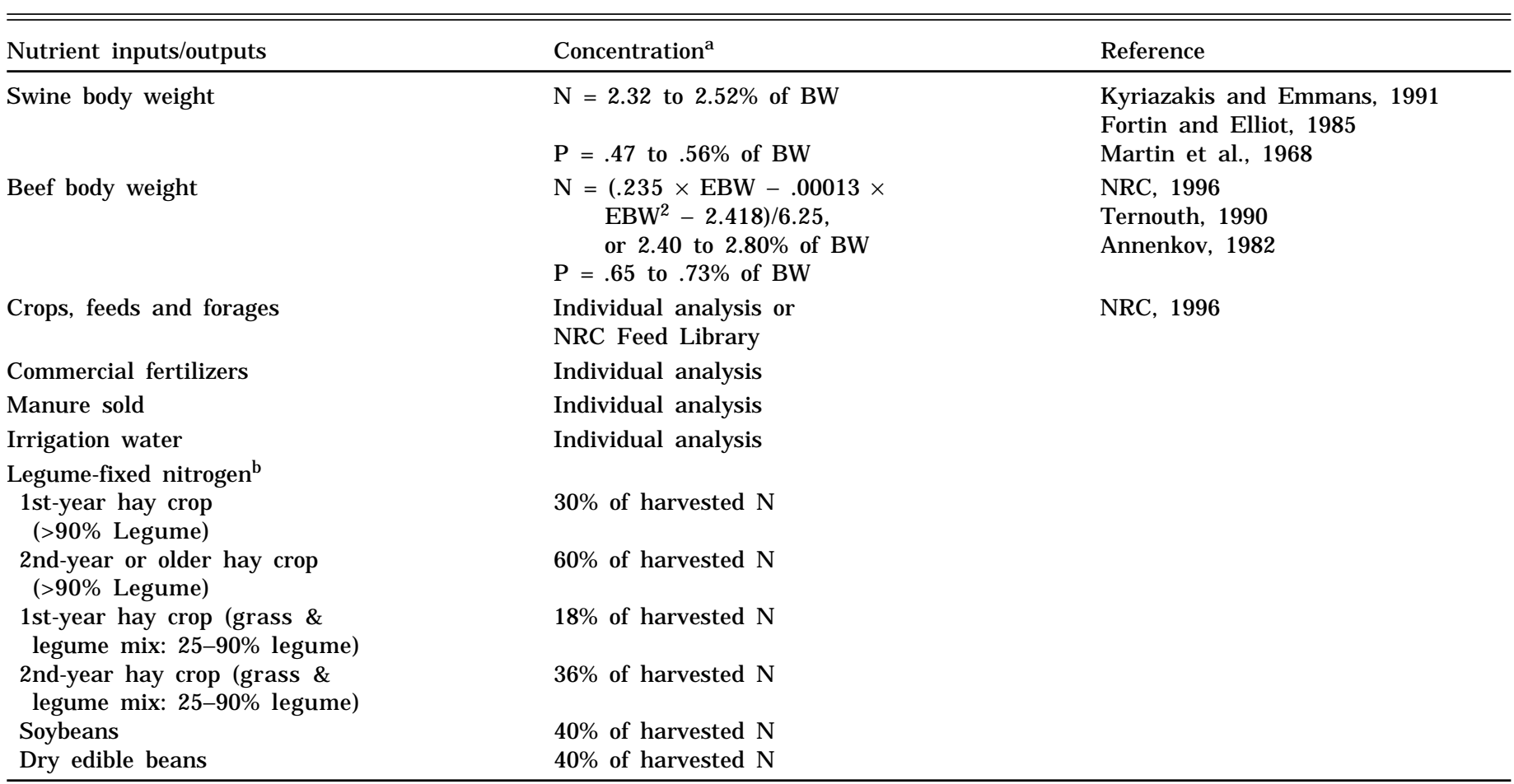

${ }^{\mathrm{a}} \mathrm{BW}=$ body weight (value provided by producer); EBW = empty body weight.

bOnly if manure has not bee applied within past year. 


\section{Results}

The average nutrient balance for all of 33 farms is summarized in Table 2 for three size groupings; 1 ) less than 250 animal units, 2) 250 to 2,500 animal units, and 3) more than 2,500 animal units. One animal unit is defined as $454 \mathrm{~kg}$ of average body weight. As the livestock production component of these farms increased in size, the land base also increased. However, the land base relative to number of animal units decreased for larger livestock operations, indicating a smaller available land base for managing similar quantities of nutrients. For example, farms with less than 250 animal units managed 1.5 ha/ animal unit as compared with .1 ha/animal unit for farms with mroe than 2,500 animal units.

The magnitude of nutrient inputs, managed outputs, and imbalance also increased with size. However, the nutrient imbalance ratio showed little change with size of the operation. Substantial variation in both nitrogen and phosphorus balance (Figures 2 and 3) existed between individual farms. Farm size alone provides only a limited explanation for the observed variation. Some of the largest nutrient imbalances were observed for farms with 100 to 1,000 animal units.

A neutral or negative phosphorus balance was observed for several of the livestock operations, indicating equal or greater managed outputs than inputs of phosphorus (Figure 3). Klausner (1995), Lanyon and Beegle (1989), and other studies of nutrient balance have not observed neutral or negative phosphorus balances. In fact, nutrient balance ratios of less than 2:1 have not appeared in the literature. These farms tended to have fewer livestock numbers and significant land bases and were commonly removing more phosphorus as crops than were being added as commercial fertilizer. These farms were likely drawing on soil phosphorus reserves during the one year for which the nutrient balance was estimated. In addition, three larger feedlots exhibited a neutral phosphorus balance. These livestock operations were actively exporting manure nutrients to off-farm customers. Neutral or negative nitrogen balances were far less frequent, although three small swine operations with significant land bases exhibited a negative nitrogen balance.

The degree of integration of crop and livestock enterprises is often considered an indicator of the potential nutrient balance (Klausner, 1995). For the 33 participating farms, the phosphorus balance again sows substantial variation when plotted against the density of livestock to land base (Figure 4). All livestock operations with negative phosphorus balances had more than .6 ha cropped per animal unit. The data would suggest that these farms were drawing on soil phosphorus reserves for meeting crop needs during the time period for measuring nutrient balance. Two cattle feedlots with almost no land base also achieved a neutral phosphorus balance as a result of manure exports. The degree of integration of crop and livestock production provides only limited explanation for the variation observed.

The source of nutrient inputs to livestock operations, including legume fixed nitrogen, purchased commercial fertilizers, purchased feeds, and purchased animals, is illustrated in Figure 5 (nitrates in irrigation water were evaluated but proved inconsequential). Purchased animal feeds were an important source of the nitrogen and phosphorus inputs. Nitrogen inputs as feed varied from 33 to $77 \%$ of total nitrogen inputs for farms with less than 250 animal units and more than 2,500 animal units, respectively. Phosphorus inputs as feed show less variation, ranging from 62 to $71 \%$ of total inputs for the same livestock groupings. Klausner (1995) observed similar levels of purchased animal feed contribution to total farm nitrogen and phosphorus inputs.

Supplementation of swine diets with mineral phosphorus was an important contributor to the phosphorus inputs for smaller livestock operations. Of the 16 participating swine farms, nine provided feed data from which mineral phosphorus purchases could be separated and quantified. On these nine farms, mineral phosphorus represented just over $60 \%$ of the total phosphorus inputs as feed and approximately $1 / 3$ of the total farm inputs of phosphorus.

Commercial fertilizer was the most significant nitrogen input for livestock operations with less than 2,500 animal units. Fertilizer was also an important source of phosphorus input for these same farms, although not as large as feed. Efforts to reduce fertilizer inputs by more efficient utilization of manure nutrients are likely to be most effective in addressing nitrogen issues among small and medium livestock operations. However, commercial fertilizer was an insignificant nutrient input for the livestock operations with more than 2,500 animal units ( $2 \%$ of nitrogen inputs and $1 \%$ of phosphorus inputs). Nutrient management will need to address more than just fertilizer nutrients to successfully address nutrient imbalances for many livestock operations.

Animal purchases represented less than $30 \%$ of the nitrogen inputs. Smaller operations, which were predominantly swine production units (often farrowing-to-finish or farrowing-to- feeder), included only 
Table 2. Average characteristics and nutrient balance for 33 Nebraska livestock farms

\begin{tabular}{|c|c|c|c|}
\hline Item & $\begin{array}{c}>250 \\
\text { animal } \\
\text { units }\end{array}$ & $\begin{array}{c}250-2,500 \\
\text { animal } \\
\text { units }\end{array}$ & $\begin{array}{c}>2,500 \\
\text { animal } \\
\text { units }\end{array}$ \\
\hline \multicolumn{4}{|c|}{ Farm characteristics } \\
\hline Number of livestock units & 12 & 13 & 8 \\
\hline Animal units $(454 \mathrm{~kg})$ & 154 & 668 & 7,597 \\
\hline Cropland, ha/animal unit & 1.5 & .6 & .1 \\
\hline \multicolumn{4}{|c|}{ Nitrogen balance, $\mathrm{Mg} / \mathrm{yr}$} \\
\hline Inputs & 34 & 92 & 836 \\
\hline Managed outputs & -23 & -38 & -368 \\
\hline Inventory change ${ }^{a}$ & -3 & -8 & -2 \\
\hline $\mathrm{N}$ imbalance, $\mathrm{Mg} / \mathrm{yr}$ & 8 & 46 & 466 \\
\hline Inputs/Outputs ${ }^{\mathrm{b}}$ & 1.8:1 & $2.4: 1$ & 2.3:1 \\
\hline \multicolumn{4}{|c|}{ Phosphorus balance, $\mathrm{Mg} / \mathrm{yr}$} \\
\hline Inputs & 4.6 & 12.0 & 163 \\
\hline Managed outputs & -3.7 & -7.9 & -102 \\
\hline Inventory change ${ }^{a}$ & -.3 & -1.3 & -1 \\
\hline $\mathrm{P}$ imbalance, $\mathrm{Mg} / \mathrm{yr}$ & .6 & 2.9 & 60 \\
\hline Inputs/Outputs ${ }^{\mathrm{b}}$ & $1.6: 1$ & $1.6: 1$ & $1.6: 1$ \\
\hline
\end{tabular}

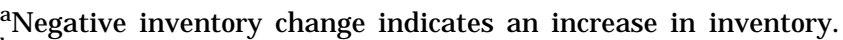

bPhosphorus imbalance ratio shown is an average that equally weight values from each livestock operation within a grouping. It cannot be calculated from the previous input and output values contained in the table.

small nutrient inputs as animals. Legume-fixed nitrogen accounts for as much as $15 \%$ of the inputs on smaller farms. Irrigation water nitrogen inputs were very small or nonexistent for the observed farms.

Marketed crops were typically the largest output (54 to $72 \%$ of nitrogen outputs) for farms less than 2,500 animals (Figure 6). For farms greater than 2,500 animal units, animal products were observed to be the largest nutrient output $(65 \%$ of nitrogen outputs). Manure transported to off-farm uses was an

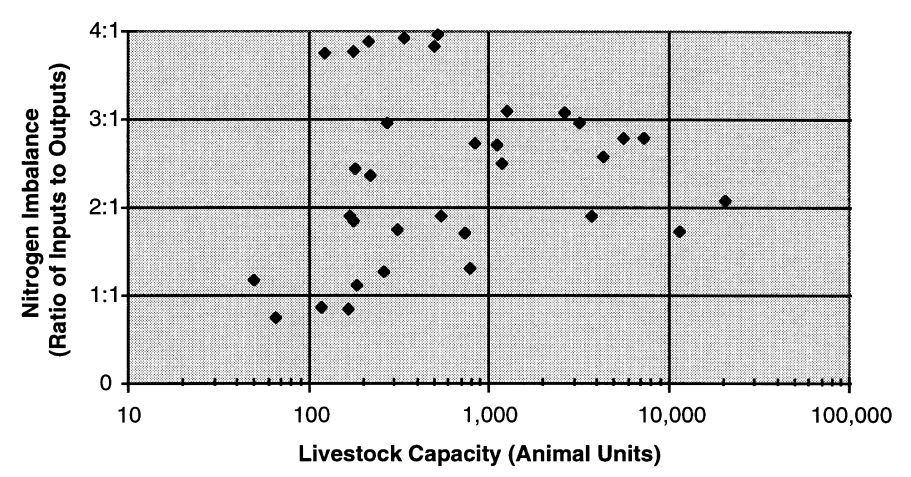

Figure 2. Nitrogen balance vs size for 33 Nebraska livestock operations.

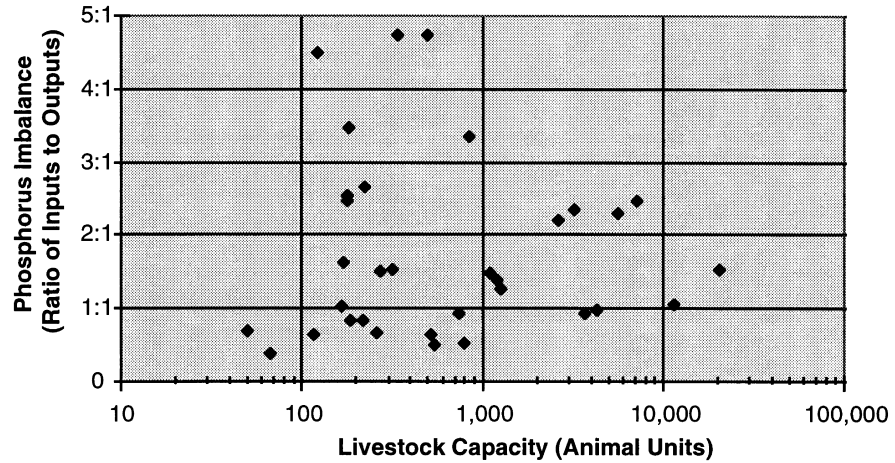

Figure 3. Phosphorus balance vs size for 33 Nebraska livestock operations.

important contributor (31\%), and crop production nutrient outputs were negligible for larger operations.

The distribution of managed nitrogen outputs from a farm (animal products vs marketed crops vs exported manure) provides some indication of the relative importance of crop and livestock production within a system. As livestock products represent an increasing part of the products marketed from a farm, the nutrient imbalance was observed to increase for the 33 observed operations (Figure 7). Lanyon (1993) described the potential for this trend. On cash-crop farms, Lanyon indicated that the easily recognized connection between crop production and purchased fertilizer inputs provides incentive for producers to use nutrients efficiently. The environment is protected because nutrients are used efficiently in crop production. Conversely, he suggests that a less evident connection exists between purchased feed nutrient inputs and crop production (and environmental quality) for a modern livestock operation. A resulting environmental impact is more likely. The observation

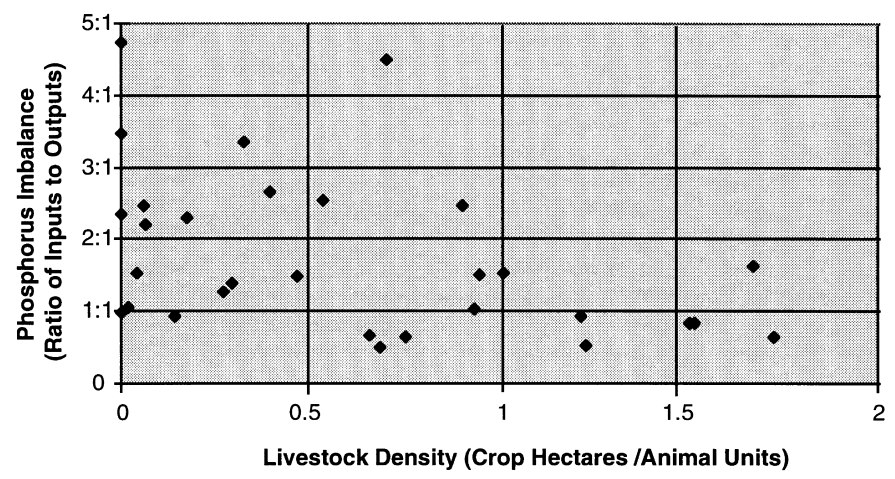

Figure 4. Phosphorus balance vs crop land to animal density for 33 Nebraska livestock farms. 


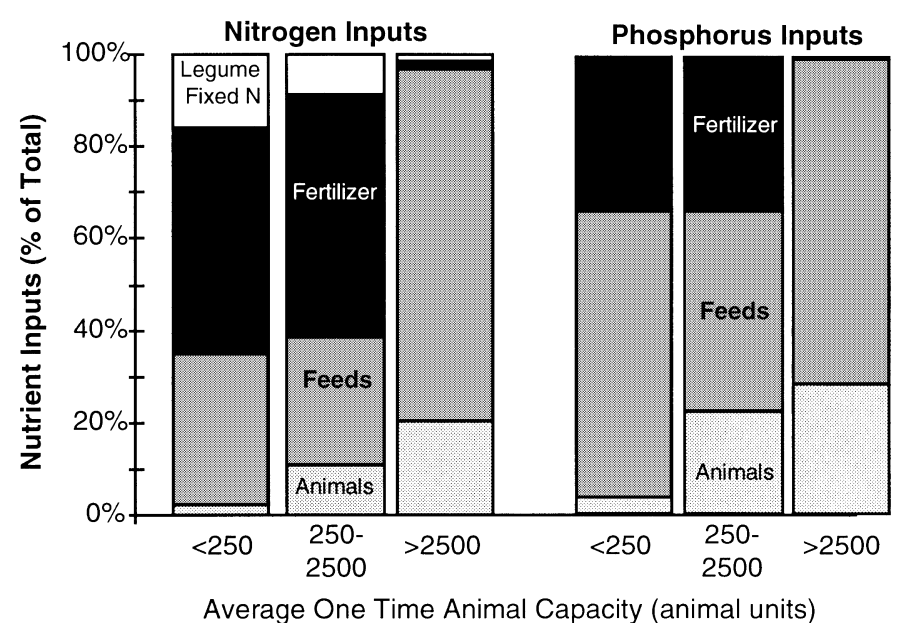

Figure 5. Relative sources of nitrogen and phosphorus inputs with different-sized Nebraska livestock operations.

that nutrient imbalance grows with greater emphasis on animal production, as seen in Figure 7, supports Lanyon's logic.

\section{Discussion}

This study highlights several critical implcations relative to management of nutrients within livestock operations in harmony with the environment. First, an assessment of environmental risk based strictly on

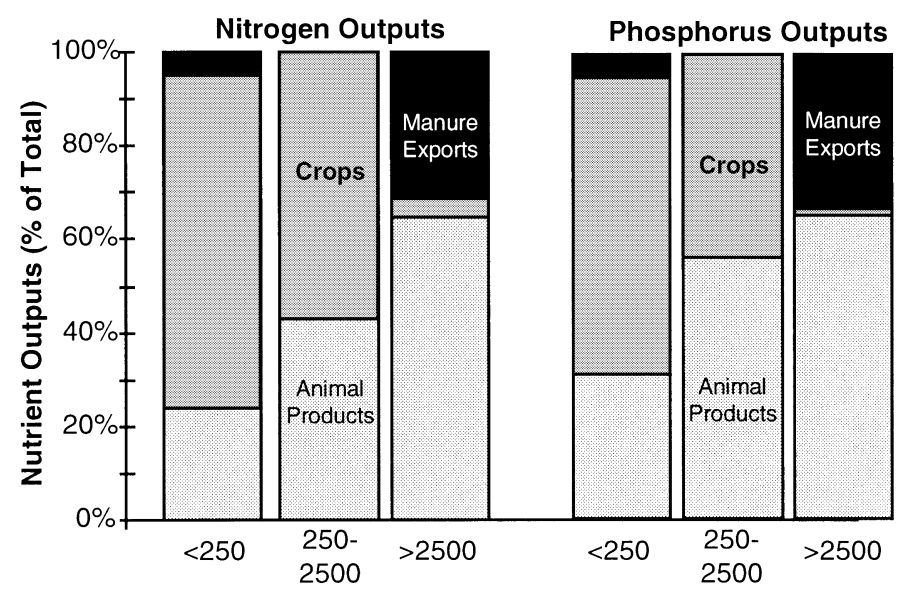

Average One Time Animal Capacity (animal units)

Figure 6. Relative sources of nitrogen and phosphorus outputs with different-sized Nebraska livestock operations.

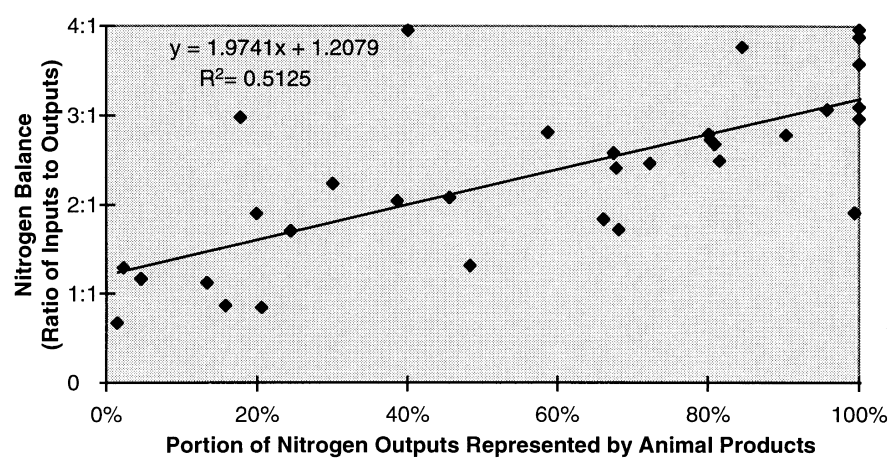

Figure 7. Impact of outputs from livestock farm in the form of animal products on nitrogen balance.

factors such as livestock herd size or livestock-to-crop land density oversimplifies a complex issue. Both factors provided a very limited explanation of the variation in observed nutrient balance. Having neither smaller-sized livestock operations or operations better integrated with crop production ensured that a "suitable" nutrient balance resulted. Other factors, including management-related decision, apparently play critical roles in determining nutrient balance.

Second, evaluating livestock systems' nutrient balance from a whole-farm perspective provides a more complete picture of the driving forces behind nutrient-related environmental challenges associated with livestock. The original sources of these nutrient inputs are clearly identified, which in turn suggest management strategies for reducing excess nutrient inputs or options for increasing nutrient outputs. Within this context, the value of specific management strategies can be better evaluated.

Based on a whole-farm nutrient balance, the following three management strategies were identified that offer significant value to reducing nutrient imbalances.

Efficient Use of Manure Nutrients in Crop Production. By accurately crediting manure nutrients in a cropping program, the purchases of commercial fertilizer can be reduced or eliminated and the risk to the environmentl minimized. Some alternative cropping programs may also allow greater utilization of manure and compost nutrients. These practices are especially important to livestock operations with significant crop production and large purchases of commercial fertilizer. However, commercial fertilizer represents a small nutrient input on most larger livestock operations. Larger livestock operations will gain little environmental benefit from more efficient utilization 
Table 3. Nutrient imbalance for cattle operations as influence by their purchase of by-products of ethanol production and corn processing

\begin{tabular}{|c|c|c|c|c|}
\hline \multirow[b]{2}{*}{ Item } & \multicolumn{2}{|c|}{ Nutrient in:out ratio } & \multicolumn{2}{|c|}{ Farm characteristics } \\
\hline & $\mathrm{N}$ & $\mathrm{P}$ & Animal units & $\mathrm{ha} / \mathrm{AU}^{\mathrm{a}}$ \\
\hline \multicolumn{5}{|l|}{ By-product purchased? } \\
\hline Yes ( 7 cattle operations) & $2.6: 1$ & $2.0: 1$ & 6,500 & 1 \\
\hline No (9 cattle operations) & $2.5: 1$ & $1.1: 1$ & 1,500 & .2 \\
\hline \multicolumn{5}{|l|}{ By-product purchased? } \\
\hline Yes & $2.8: 1$ & 2.3:1 & 5,600 & .9 \\
\hline No & $1.9: 1$ & $0.9: 1$ & 3,700 & 1.1 \\
\hline
\end{tabular}

${ }^{\mathrm{a}} \mathrm{AU}=$ One animal unit, or $454 \mathrm{~kg}$ (1,000 pounds) of live animal weight.

of manure nutrients within their cropping program. In addition, this strategy offers greater benefit for nitrogen as opposed to phosphorus-related imbalances.

Many factors influence the land base needs for utilizing nutrients in the manure. For example, anywhere from .08 to .32 ha of land is needed under typical Nebraska conditions to manage the nitrogen from one animal unit of pork depending on the manure management system. For open feedlot production of beef cattle, agronomic application of nitrogen and phosphorus requires roughly .16 and .65 ha acres of land per animal unit of beef production, respectively. However, access to sufficient land alone provides little assurance of a reasonable nutrient balance, as illustrated by Figure 4 .

Alternative Livestock Feeding Programs. Opportunities are available for reducing both nitrogen and phosphorus inputs by alternative livestock feeding programs. For example, phytase in corn-soybean diets for swine will increase nutritional availability of phytic acid phosphorus and reduce the purchases of mineral phosphorus sources (Cromwell and Coffey, 1995; NRC, 1998). This study observed that significant reductions in mineral phosphorus use on swine operations would also contribute to a substantial improvement in nutrient balance.

Opportunity may also exist to reduce excess phosphorus in beef cattle diets (E rickson et al., 1998a,b). By-products of ethanol and corn processing, attractive feed alternatives for some cattlemen, are typically high in phosphorus concentrations resulting in finished rations with excess phosphorus levels. Participating operations who used these by-products experienced greater phosphorus imbalance compared with operations that did not (Table 3 ). Both groups had very similar nitrogen balance. However, these two groups had different characteristics, including size of livestock operation and available crop base per animal unit, suggesting that other factors might influence the observed imbalances. A comparison of two livestock operations with comparable size and crop base further supported a phosphorus balance favoring the producer not purchasing by-products of corn processing. The high phosphorus content of corn processing byproducts is a potential contributor to higher phosphorus imbalances. The economic benefits of this feed option will need to be weighed against the potentially greater manure management costs and(or) increased environmental risks.

Marketing of Manure Nutrients. Several larger livestock operations with limited or no land base were observed to have a relatively small phosphorus imbalance (see Figure 4). A closer review of data from three of those farms indicates an active effort to move manure away to neighboring crop producers (Table 4). The marketing of manure creates a new managed output, similar to the sale of crops or livestock products. For two large Nebraska feedlots, mareting of manure moved sufficient phosphorus to off-farm uses so as to eliminate any phosphorus imbalance (ratio of 1.0:1 and 1.1:1 on Farms \#1 and \#2, respectively). These farms have achieved a relative level of nutrient sustainability that should prevent future accumulations of phosphorus (i.e., increasing soil phosphorus levels) on these operations. Marketing of manure has reduced Farm \#3's phosphorus imbalance by $112 \mathrm{Mg} /$ yr (124 tons/yr).

\section{Conclusions}

Evaluating the environmental risk of a livestock operation based on an accounting of all nutrient 
Table 4. Phosphorus balance for three livestock operations actively involved in marketing of manure to off-farm customers

\begin{tabular}{|c|c|c|c|c|c|c|}
\hline \multirow{2}{*}{$\begin{array}{l}\text { Is manure marketed } \\
\text { to off-farm } \\
\text { customers? }\end{array}$} & \multicolumn{2}{|c|}{$\begin{array}{c}\text { Farm \#1, } \\
4,300 \text { animal units }\end{array}$} & \multicolumn{2}{|c|}{$\begin{array}{c}\text { Farm } \# 2, \\
11,500 \text { animal units }\end{array}$} & \multicolumn{2}{|c|}{$\begin{array}{c}\text { Farm \#3, } \\
20,600 \text { animal units }\end{array}$} \\
\hline & $\mathrm{No}^{\mathrm{a}}$ & $Y_{e s}^{b}$ & $\mathrm{No}^{\mathrm{a}}$ & $Y_{e s}^{b}$ & $\mathrm{No}^{\mathrm{a}}$ & Yes $^{b}$ \\
\hline \multicolumn{7}{|l|}{ Phosphorus imbalance } \\
\hline $\mathrm{Mg} / \mathrm{yr}$ & 52 & -1 & 112 & 12 & 254 & 142 \\
\hline In:out ratio & 2.5 to 1 & 1.0 to 1 & 2.1 to 1 & 1.1 to 1 & 2.6 to 1 & 1.5 to 1 \\
\hline
\end{tabular}

aphosphorus imbalance if no manure was marketed to off-farm sources.

bphosphorus imbalance including manure marketed to off-farm sources represents measured livestock operation nutrient imbalance.

inputs and outputs provides a unique perspective of the driving forces behind nutrient-related environmental issues. Conclusions drawn from a review of the nutrient balance on 33 Nebraska farms that include cattle and swine confinement include the following:

1. Most farms exhibit substantially greater nitrogen inputs than managed outputs. The majority of farms also exhibited an accumulation of phosphorus.

2. Livestock feed purchases amount to a significant source of nutrient inputs to livestock operations. Purchased feeds were the primary source of nitrogen input for farms with more than 2,500 animal units and the primary source of phosphorus for all sizes of operations.

3. Substantial variation exists between individual farms. The size of the livestock component and the degree of integration of livestock and cropping systems (crop hectares per animal unit) provided only a limited explanation of the observed variation.

4. Alternative management strategies are needed for addressing a nutrient imbalance. These strategies must vary for individual livestock operations dependent on the primary sources of nutrient inputs and availability of crop land. Marketing of manure nutrients was observed to produce a "sustainable" nutrient balance for several larger livestock operations with limited crop land.

\section{Implications}

Livestock producers have a responsibility to manage for a balanced nutrient system. The preferred strategy for achieving this goal varies with individual situations. For systems with sufficient land base for utilizing manure nutrients, this strategy should focus on maximizing their use as a fertilizer and on reducing commercial fertilizer inputs to achieve a nutrient balance. Alternative feeding programs can focus on phosphorus reduction in manure to provide a nutrient source better matched to crop nitrogen and to phosphorus needs. When insufficient land base is available for utilizing manure nutrients, dietary options for reducing manure nitrogen and phosphorus and marketing of manure nutrients to off-farm customers will be fundamental to achieving nutrient balance. For manure to be accepted by off-farm customers, it must be viewed as a valued resource with a focus on efficient nutrient use in cropping programs and limiting of nuisance issues.

\section{Literature Cited}

Aarts, H.F.M., E. E. Biewinga, and H. Van Keulen. 1992. Dairy farming systems based on efficient nutrient management. Neth. J. Agric. Sci. 40:285-299.

Annenkov, B. N. 1982. Mineral Feeding of Pigs. In: V. I. Georgievskii, B. N. Annenkov, and V. I. Samokhined (Ed.) Mineral Nutrition of Animals. p 355. Butterworth and Company, London, England.

CAST. 1996. Integrated animal waste management. Task Force Report No. 128. Council for Agricultural Science and Technology, Ames, lowa.

Cromwell, G. L., and R. D. Coffey. 1995. Nutrient management from feed to field. Presented at the World Pork Expo., J une 9-10, Des Moines, IA.

Eghball, B. 1996. Phosphorus and nitrogen based manure and compost application. Manure Matters Newsl. 2:9. University of Nebraska, Lincoln. Avaliable at: http://www.ianr.unl.edu/manure/v2n9-96.html.

Erickson, G., M. Klemesrud, T. Milton, and T. Klopfenstein. 1998a. Phosphorus requirements of finishing yearlings. 1998 Nebraska Beef Cattle Report. pp 78-80.

Erickson, G., T. Milton, and T. Klopfenstein. 1998b. Evaluation of 1996 NRC for protein and phosphorus requirements of finishing cattle. 1998 Nebraska Beef Cattle Report. pp 84-85. 
Fortin, A., and J. I. Elliot. 1985. Relationships between backfat thickness and chemical composition of the body and components of swine. J. Anim. Sci. 61:158-164.

Frink, C. R. 1969. Water pollution potential estimated from farm nutrient budgets. Agron. J . 61:550-553.

Klausner, S. 1995. Nutrient management planning. In: K. Steele (Ed.) Animal Waste and the Land-Water Interface. pp 383-392. Lewis Publishers, New York.

Klopfenstein, T., D. Shain, and S. Bierman. 1995. Ruminant animal nutrient management options. University of Nebraska Agricultural Research and Development Center Symposium. pp 15-21.

Kyriazakis, I., and G. C. Emmans. 1991. Diet selection in pigs: Dietary choices made by growing pigs following a period of underfeeding with protein. Anim. Prod. 52:337-346.

Lanyon, L. E., and D. B. Beegle. 1989. The role of on-farm nutrient balance assessments in an integrated approach on nutrient management. J. Soil Water Conserv. 44(2):164-168.

Lanyon, L. E., and D. B. Beegle. 1993. A nutrient management approach for Pennsylvania: Plant nutrient stocks and flows. Penn State Agronomy Facts 38-B.

Lugar, R. G., and P. J . Leahy. 1995. Animal agriculture. Information on waste management and water quality issues. GAO Briefing Report to the Committee on Agriculture, Nutrition and Forestry, U.S. Senate.

Martin, T. G., E. G. Stant, J r., W. V. Kessler, M. D. J udge, and J . E. Christian. 1968. Associations of body potassium, chemical com- position and carcass measurements with fat:lean composition determined by physical separation. Body Composition in Animals and Man. Natl. Acad. Sci. Publ. 1598:428.

Mueller, D. K., P. A. Hamilton, D. R. Helsel, K. J . Hitt, and B. C. Ruddy. 1995. Nutrients in ground water and surface water of the United States. US Geological Survey. Water Resources Investigations Report 95-4031. Denver, CO.

NRC. 1996. Nutrient Requirements of Beef Cattle. National Academy Press, Washington, DC.

NRC. 1998. Nutrient Requirements for Swine (10th Rev. Ed.). National Academy Press, Washington, DC.

Smolen, M. D., D. E. Storm, D. Peel, and P. Kenkel. 1994. Mass balance analysis of nutrient flow through feed and waste in the livestock industry in the southern plains. Great Plains Animal Waste Conference on Confined Animal Production and Water Quality. National Cattlemen's Association, Englewood, CO. pp 168-174.

Ternouth, H. 1990. Phosphorus and beef production in northern Australia. 3. Phosphorus in cattle-A review. Trop. Grassl. 24: 159-169.

Watts, P. J ., E. A. Gardnes, R. W. Tucker, and K. D. Casey. 1994. Mass-balance approach to design of nutrient management systems at cattle feedlots. Great Plains Animal Waste Conference on Confined Animal Production and Water Quality. National Cattlemen's Association, Englewood, CO. 